\title{
Ambient Air Quality Evaluation: A Comparative Study in China and Pakistan
}

\author{
Yasir Niaz $^{1 *}$, Jiti Zhou1, Munawar Iqbal², Abdul Nasir ${ }^{3}$, Bin Dong ${ }^{1}$ \\ ${ }^{1}$ Key Laboratory of Industrial Ecology and Environmental Engineering, Ministry of Education, \\ School of Environmental Science and Technology, Dalian University of Technology, Dalian 116024, China \\ ${ }^{2}$ National Centre of Excellence in Physical Chemistry, University of Peshawar, Peshawar 25120, Pakistan \\ ${ }^{3}$ Department of Structures and Environmental Engineering, University of Agriculture, Faisalabad 38000, Pakistan
}

Received: 26 January 2015

Accepted: 15 March 2015

\begin{abstract}
Vehicle and industrial emissions are responsible for a considerable share of urban air pollution concentrations. We conducted a comparative study in Dalian, China and Faisalabad, Pakistan to reevaluate $\mathrm{NO}_{2}, \mathrm{SO}_{2}$, and $\mathrm{CO}$ concentrations. Our study was conducted over the course of one year at different stations in both cities, and measured values were compared with ambient air quality standards such as NEQS-Pakistan, NAAQSUSEPA, CNAAQS-China, and global standard WHO. The $\mathrm{NO}_{2}$ concentrations in Faisalabad varied from 185$262 \mu \mathrm{g} / \mathrm{m}^{3}$, whereas it was in the range of $44-133 \mu \mathrm{g} / \mathrm{m}^{3}$ in Dalian. The $\mathrm{SO}_{2}$ concentration was found in the range of $66-190 \mu \mathrm{g} / \mathrm{m}^{3}$ and $56-128 \mu \mathrm{g} / \mathrm{m}^{3}$, while CO varied from $5.4-22.3 \mathrm{mg} / \mathrm{m}^{3}$ and $0.3-2.8 \mathrm{mg} / \mathrm{m}^{3}$, respectively, in Faisalabad and Dalian. The annual average $\mathrm{NO}_{2}, \mathrm{SO}_{2}$, and $\mathrm{CO}$ concentrations were below the permissible limits in Dalian; however, the measured values were considerably higher in Faisalabad. Our results are the first to compare air quality of two countries at different stations and highlight the possibility of reducing air pollution by comparing conditions.
\end{abstract}

Keywords: $\mathrm{NO}_{2}, \mathrm{SO}_{2}$, CO, NEQS-Pakistan, CNAAQS-China

\section{Introduction}

The adverse impacts of air pollution on environment and human health has been a major problem due to the rapid growth of population, industrialization, and urbanization in recent decades. Many countries have established ambient air quality standards around the world together with air quality guidelines by the World Health Organization (WHO) for the protection of the global atmosphere [1].

In recent decades research has found that outdoor air pollution is harmful to health, and traffic emission is an important contributor to air pollution [2]. The mechanisms of the harmful effects of air pollution also have changed,

*e-mail: yasir.niaz1885@gmail.com with health effects connected rather to the lung deposited surface area and reactivity [3, 4]. Vehicular emissions are the major source of air pollution in urban environments. Combustion engine-produced air pollution includes carbon monoxide $(\mathrm{CO})$, nitrogen oxides $\left(\mathrm{NO}_{\mathrm{x}}\right)$, and sulphur dioxide $\left(\mathrm{SO}_{2}\right)$. Pollution from heavy vehicles one of the major anthropogenic source of the gaseous pollutants $\mathrm{CO}, \mathrm{NO}_{\mathrm{x}}$, and NMHCs, as well as fine particles [5-7].

During the last decade Pakistan has seen an extensive escalation in population growth, urbanization, and industrialization, together with a great increase in motorization and energy use. As a result, a substantial rise has taken place in the types and number of emission sources of various air pollutants: $\mathrm{PM}, \mathrm{SO}_{2}, \mathrm{O}_{3}, \mathrm{CO}, \mathrm{NO}_{2}$, and $\mathrm{Pb}$. However, due to the lack of air quality management capabilities, the country is suffering from deterioration of air quality. Evidence 
from various governmental organizations and international bodies has indicated that air pollution is a significant risk to the environment, quality of life, and health of the resident [8]. The rapid growth of urbanization and industrial development in the past two decades also greatly deteriorated air quality in China. Air pollution now has become one of the top environmental concerns in China. The primary air pollutants, namely $\mathrm{NO}_{2}$ and $\mathrm{SO}_{2}$ in Chinese cities, are mainly emitted from industrial and domestic energy production, burning, and transportation [9-17].

This study compared the ambient air quality of two cities of two separate countries (Faisalabad-, Pakistan and Dalian, China). The principle objectives were:

1) to measure the concentrations of $\mathrm{NO}_{2}, \mathrm{SO}_{2}$, and $\mathrm{CO}$ in the urban areas of Dalian and Faisalabad,

2) to compare the ambient air quality of Faisalabad and Dalian date-wise as well as station-wise.

The $\mathrm{NO}_{2}, \mathrm{SO}_{2}$, and $\mathrm{CO}$ were assessed at different stations within both cities for a period of one year (JanuaryDecember, 2013). Finally, the measured air quality parameters such as $\mathrm{NO}_{2}, \mathrm{SO}_{2}$, and $\mathrm{CO}$ were compared with air pollution indexes such as NEQS-Pakistan, NAAQS-USEPA, CNAAQS-China, and WHO.

\section{Materials and Methodology}

\section{Study Area}

With a population of 6 million, Faisalabad is one of the third largest cities of Pakistan after Karachi and Lahore (formerly known as Lyallpur), and is situated at $31^{\circ} 25^{\prime} 4.8^{\prime \prime}$ $\mathrm{N}, 73^{\circ} 4^{\prime} 44.4^{\prime \prime}$ E. At present, the city has a very dense transport system with high energy consumption. According to a report by the Pakistan Statistical Year Book 2012-13, the number of registered vehicles in Faisalabad is 767,453 out of the total 9,893,373 vehicles of Punjab Province [18]. The city has elevation of $184 \mathrm{~m}$ above sea level and covers an area of 1,230 $\mathrm{km}^{2}$. Faisalabad stands in the rolling flat plains of northeastern Punjab and features hot desert-like climate because of high transpiration rates across the year. Thus the city experiences extreme climates, with summer temperatures as high as $50^{\circ} \mathrm{C}$ and winter as low as $-2^{\circ} \mathrm{C}$; mean maximum and minimum temperatures in summer are 39 and $27^{\circ} \mathrm{C}$, respectively. On the other hand, winter temperature peaks around 17 and $6^{\circ} \mathrm{C}$. Summer season usually starts from April and lasts until October, out of which May, June, and July are the hottest months. Winter lasts from November to March, during which December, January, and February are the coldest months. The average humidity in the city is $40 \%$ and pressure recorded is $1020 \mathrm{hPa}$ [19].

Dalian, with a population of 6.6 million, is one of the major cities in China, located in southern Liaoning Province. It is the southernmost city of northeastern China situated at $38^{\circ} 55^{\prime} 15^{\prime \prime} \mathrm{N}, 121^{\circ} 38^{\prime} 21^{\prime \prime} \mathrm{E}$. Dalian has heavily developed industrial areas with an elevation of $33 \mathrm{~m}$ above sea level, and the city covers $13,237 \mathrm{~km}^{2}$. Dalian has sloppy featured land and has a monsoon-influenced humid continental climate, characterized by humid summers due to
Table 1. Monitoring stations with location.

\begin{tabular}{|c|c|c|c|}
\hline \multirow{2}{*}{ No. } & \multirow{2}{*}{$\begin{array}{c}\text { Monitoring } \\
\text { Station }\end{array}$} & \multicolumn{2}{|c|}{ Locations } \\
\cline { 3 - 4 } & Latitude & Longitude \\
\hline 1 & $\begin{array}{c}\text { Clock Tower } \\
\text { Chowk }\end{array}$ & $31^{\circ} 25^{\prime} 07^{\prime \prime} \mathrm{N}$ & $7^{\circ} 04^{\prime} 44^{\prime \prime} \mathrm{E}$ \\
\hline 2 & Station Chowk & $31^{\circ} 25^{\prime} 07^{\prime \prime} \mathrm{N}$ & $7^{\circ} 05^{\prime} 43^{\prime \prime} \mathrm{E}$ \\
\hline 3 & Chenab Chowk & $31^{\circ} 24^{\prime} 47^{\prime \prime} \mathrm{N}$ & $73^{\circ} 04^{\prime} 02^{\prime \prime} \mathrm{E}$ \\
\hline 4 & D-Type Chowk & $31^{\circ} 22^{\prime} 47^{\prime \prime} \mathrm{N}$ & $73^{\circ} 04^{\prime} 19^{\prime \prime} \mathrm{E}$ \\
\hline 5 & $\begin{array}{c}\text { National Hospital } \\
\text { Chowk }\end{array}$ & $31^{\circ} 25^{\prime} 15^{\prime \prime} \mathrm{N}$ & $73^{\circ} 03^{\prime} 46^{\prime \prime} \mathrm{E}$ \\
\hline 6 & Millat Chowk & $31^{\circ} 26^{\prime} 49^{\prime \prime} \mathrm{N}$ & $73^{\circ} 05^{\prime} 48^{\prime \prime} \mathrm{E}$ \\
\hline 7 & Ganjingzi & $38^{\circ} 57^{\prime} 10.65^{\prime \prime} \mathrm{N}$ & $121^{\circ} 31^{\prime} 31.68^{\prime \prime} \mathrm{E}$ \\
\hline 8 & Zhoushuizi & $38^{\circ} 57^{\prime} 57^{\prime \prime} \mathrm{N}$ & $121^{\circ} 32^{\prime} 18^{\prime \prime} \mathrm{E}$ \\
\hline 9 & $\begin{array}{c}\text { Xinghai three } \\
\text { stations }\end{array}$ & $38^{\circ} 54^{\prime} 31.81^{\prime \prime} \mathrm{N}$ & $121^{\circ} 36^{\prime} 39.92^{\prime \prime} \mathrm{E}$ \\
\hline 10 & Qingniwaqiao & $38^{\circ} 55^{\prime} 04.82^{\prime \prime} \mathrm{N}$ & $11^{\circ} 38^{\prime} 09.16^{\prime \prime} \mathrm{E}$ \\
\hline 11 & Fujiazhuang & $38^{\circ} 52^{\prime} 05.35^{\prime \prime} \mathrm{N}$ & $11^{\circ} 37^{\prime} 29.90^{\prime \prime} \mathrm{E}$ \\
\hline 12 & Qixianling & $38^{\circ} 51^{\prime} 02.74^{\prime \prime} \mathrm{N}$ & $12^{\circ} 31^{\prime} 21.78^{\prime \prime} \mathrm{E}$ \\
\hline
\end{tabular}

the East Asian monsoon, and cold, windy, dry winters. Though it is heavily concentrated in the summer months and can greatly vary from year to year, the annual precipitation averages $602 \mathrm{~mm}$. With 2,740 hours of bright sunshine annually, the monthly percent possible sunshine ranges from $49 \%$ in July to $68 \%$ in September and October. The average humidity in the city is $56 \%$ and average pressure is recorded at $1024 \mathrm{hPa}$. The annual mean temperature is $10.90^{\circ} \mathrm{C}$. The city is witnessing a double-digit percentage increase in GDP annually since 1992. The city's GDP registered an increase of 15\%, reaching RMB 441.77 billion, while per capita GDP hit RMB 71,833 in 2009 [20].

$$
\text { Measuring } \mathrm{NO}_{2}, \mathrm{SO}_{2} \text {, and } \mathrm{CO}
$$

This study is based on 6 monitoring sites for sampling (Fig. 1 and Table 1). Data-wise and station-wise, samples were collected and analyzed from the months of January to December 2013. A total of 144 samples of each pollutant $\left(\mathrm{NO}_{2}, \mathrm{SO}_{2}\right.$, and $\left.\mathrm{CO}\right)$ were collected. A high-volume sampler was used. The samples were collected for a period of 24-hr at an average flow rate of $40 \mathrm{cfm}\left(1.13 \mathrm{~m}^{3} / \mathrm{min}\right)$ and two times per week. The concentrations of $\mathrm{NO}_{2}, \mathrm{CO}$, and $\mathrm{SO}_{2}$ were analyzed by standard methods such as carbon monoxide analyzer, non-dispersive infrared detection, 6500 -smoke meter, and gas phase chemiluminescence methods. All the collected samples were analyzed in the laboratory of the Environment Protection Department (EPD) in Faisalabad, Pakistan. The results of $\mathrm{NO}_{2}, \mathrm{SO}_{2}$, and $\mathrm{CO}$ were compared with four different regional standards like NEQS-Pakistan, USEPA-NAAQS, CNAAQS-China, and WHO (Table 2). 
The data of Dalian city's $\mathrm{NO}_{2}, \mathrm{SO}_{2}$, and CO pollutants was collected from the official website of the Dalian Environmental Protection Bureau (Dalian EPB) [20], which covers the period from January to December 2013 at different stations (Fig. 2 and Table 1). The gravimetric method is used to determine the concentrations of $\mathrm{NO}_{2}$, $\mathrm{SO}_{2}$, and $\mathrm{CO}$ at these monitoring stations [20]. $\mathrm{NO}_{2}, \mathrm{SO}_{2}$, and $\mathrm{CO}$ measured values were compared with the four different regional standards like NEQS-Pakistan, USEPANAAQS, CNAAQS-China, and WHO (Table 2).

\section{Statistical Analysis}

One-way ANOVA and t-test were performed using Microsoft Excel 2007. The concentrations were initially reported by descriptive statistics (mean and standard deviation).

\section{Results and Discussion}

\section{Comparison of $\mathrm{NO}_{2}$ at Dalian and Faisalabad Cities}

The concentration of $\mathrm{NO}_{2}$ was calculated from January to December 2013. $\mathrm{NO}_{2}$ date-wise concentration distribution in Faisalabad and Dalian is shown in Fig. 3. $\mathrm{NO}_{2}$ concentrations in Faisalabad varied from 185 to $262 \mu \mathrm{g} / \mathrm{m}^{3}$, with an average of $219 \mu \mathrm{g} / \mathrm{m}^{3}$. These concentrations are rel-
Table 2 . Ambient air quality standards.

\begin{tabular}{|c|c|c|c|c|}
\hline Standards & $\begin{array}{c}\text { Time- } \\
\text { Weighted } \\
\text { Annual Avg. }\end{array}$ & $\begin{array}{c}\mathrm{NO}_{2} \\
\left(\mu \mathrm{g} / \mathrm{m}^{3}\right)\end{array}$ & $\begin{array}{c}\mathrm{SO}_{2} \\
\left(\mu \mathrm{g} / \mathrm{m}^{3}\right)\end{array}$ & $\begin{array}{c}\mathrm{CO} \\
\left(\mathrm{mg} / \mathrm{m}^{3}\right)\end{array}$ \\
\hline NEQS-PAK & $24-\mathrm{hr}^{*}$ & 80 & 120 & 10 \\
\hline NAAQS-USEPA & $24-\mathrm{hr}^{* *}$ & 100 & 200 & 10 \\
\hline CNAAQS-CHINA & $24-\mathrm{hr}^{* * *}$ & 80 & 150 & 10 \\
\hline WHO & $24-\mathrm{hr}$ & 40 & 20 & 10 \\
\hline
\end{tabular}

*24 hourly/8 hourly values should be met $98 \%$ of the in a year; $2 \%$ of the time it may exceed, but not on two consecutive days. **Not to be exceeded more than once per year on average over three years, $98 \%$ average over three years.

***Grade II is for residential, commercial, industrial and rural areas.

atively higher than the other cities in the regions like Lahore-Pak $\left(76 \mu \mathrm{g} / \mathrm{m}^{3}\right)$, Karachi-Pak $\left(76 \mu \mathrm{g} / \mathrm{m}^{3}\right)$, Islamabad-Pak $\left(30 \mu \mathrm{g} / \mathrm{m}^{3}\right)$, Beijing-China $\left(122 \mu \mathrm{g} / \mathrm{m}^{3}\right)$, Shanghai-China $\left(53 \mu \mathrm{g} / \mathrm{m}^{3}\right)$, Tokyo-Japan $\left(55 \mu \mathrm{g} / \mathrm{m}^{3}\right)$, Mumbai-India $\left(43 \mu \mathrm{g} / \mathrm{m}^{3}\right)$, and Kolkata-India $\left(37 \mu \mathrm{g} / \mathrm{m}^{3}\right)$ $[21,22]$. The minimum value of $\mathrm{NO}_{2}$ concentration was found to be $185 \mu \mathrm{g} / \mathrm{m}^{3}$ in April 2013, whereas the maximum was recorded at $262 \mu \mathrm{g} / \mathrm{m}^{3}$ in August 2013. The average $\mathrm{NO}_{2}$ concentration in Faisalabad through the year was higher than the standards of NEQS, USEPA, WHO, and CNAAQS. The average $\mathrm{NO}_{2}$ concentration during the cold period (10 November to 25 March) was found to be 200

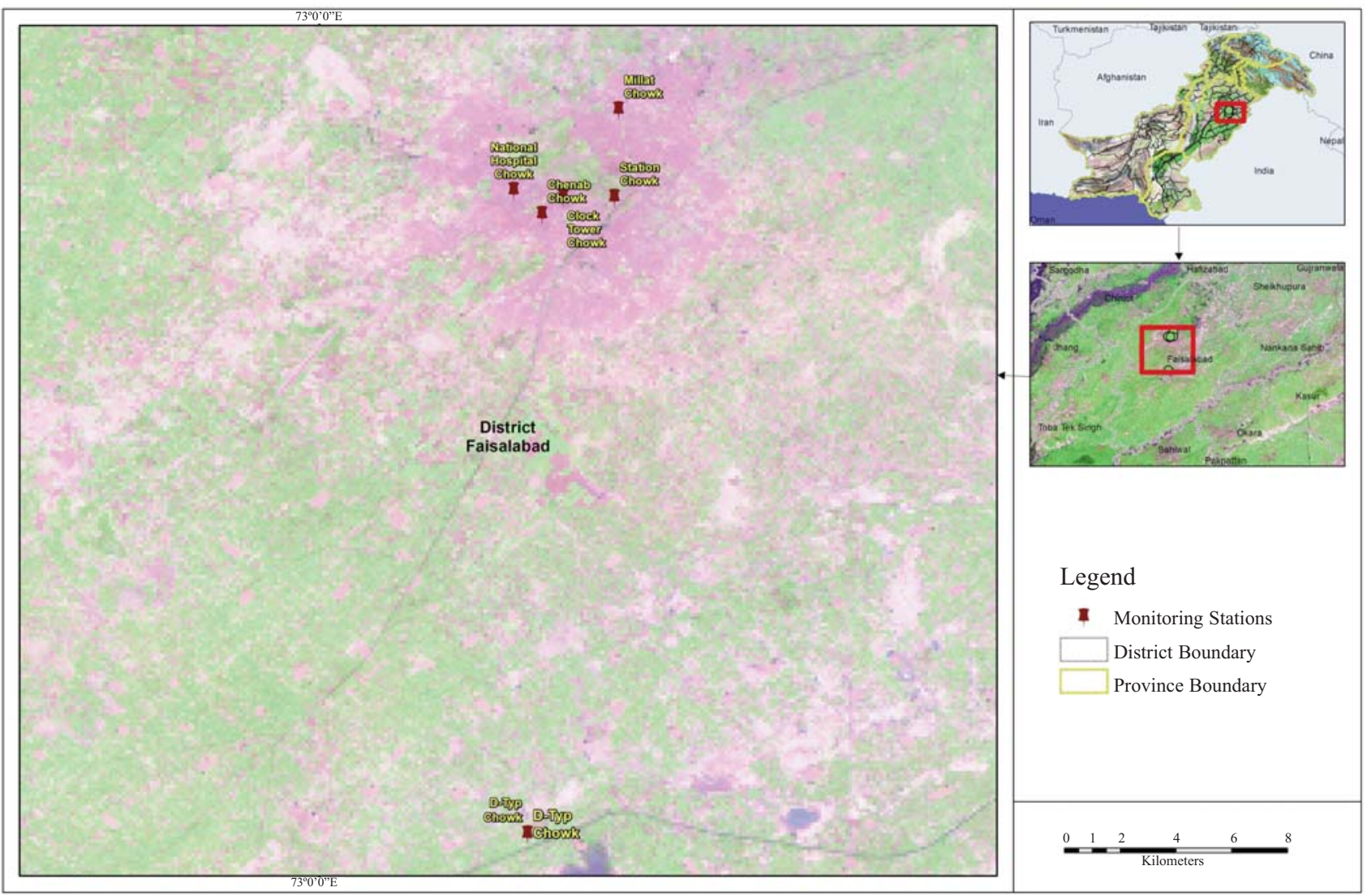

Fig. 1. Map of selected stations in Faisalabad, Pakistan. 


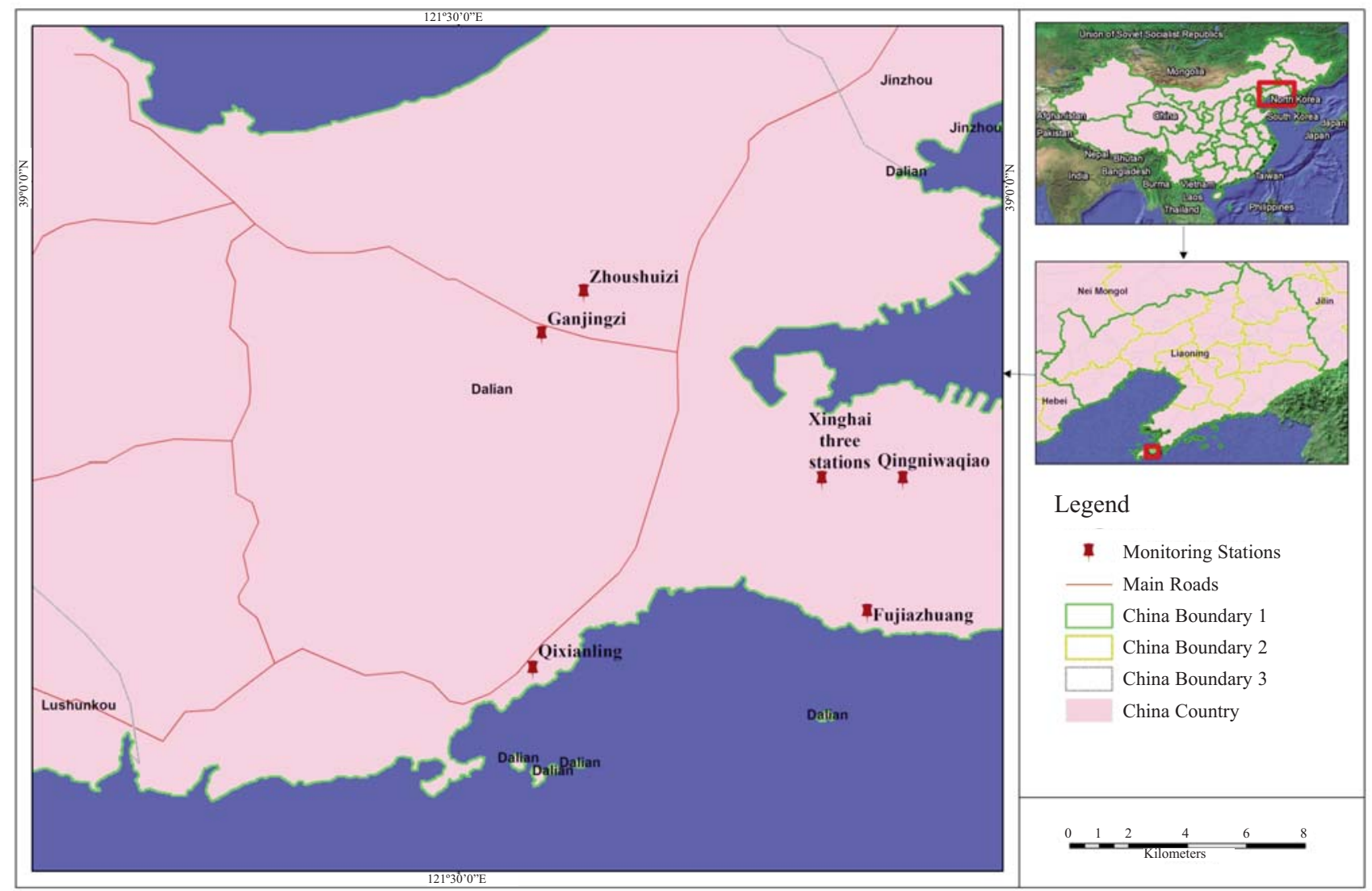

Fig. 2. Map of selected stations in Dalian P.R. China.

$\mu \mathrm{g} / \mathrm{m}^{3}$ and in the warm period (10 April to 25 October) it was found to be $232 \mu \mathrm{g} / \mathrm{m}^{3}$. Overall, $100 \%$ values were beyond the permissible limit of NEQS, USEPA, WHO, and CNAAQS standards $80,100,40$, and $80 \mu \mathrm{g} / \mathrm{m}^{3}$, respectively (Table 2).
$\mathrm{NO}_{2}$ concentrations in Dalian varied from 44 to 133 $\mu \mathrm{g} / \mathrm{m}^{3}$, with an average of $74 \mu \mathrm{g} / \mathrm{m}^{3}$. These concentrations are relatively higher than the other cities in the regions, like Islamabad-Pak $\left(30 \mu \mathrm{g} / \mathrm{m}^{3}\right)$, Shanghai-China $\left(53 \mu \mathrm{g} / \mathrm{m}^{3}\right)$, Tokyo-Japan $\left(55 \mu \mathrm{g} / \mathrm{m}^{3}\right)$, Mumbai-India $\left(43 \mu \mathrm{g} / \mathrm{m}^{3}\right)$, and

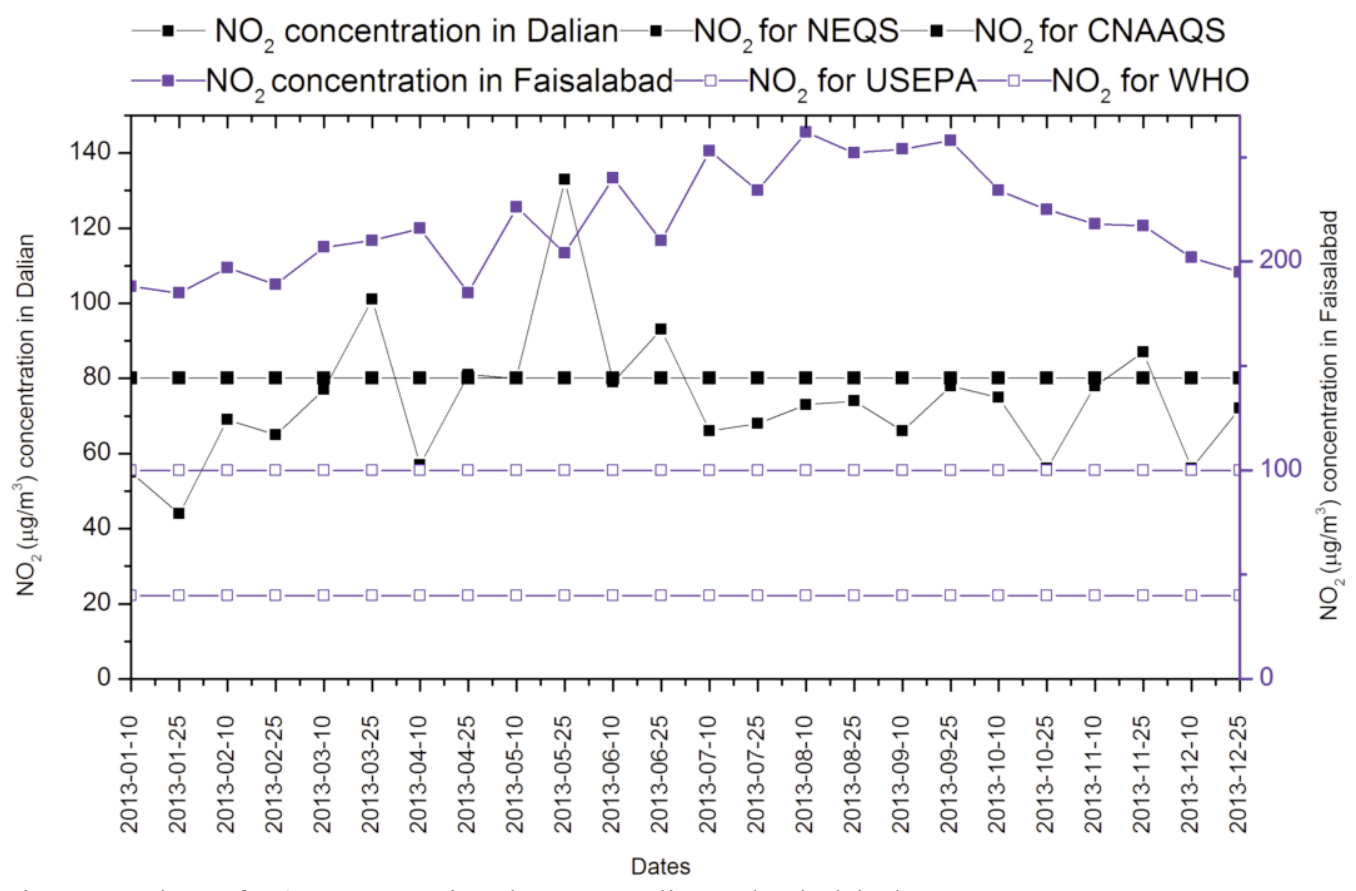

Fig. 3. Date-wise comparison of $\mathrm{NO}_{2}$ concentrations between Dalian and Faisalabad. 


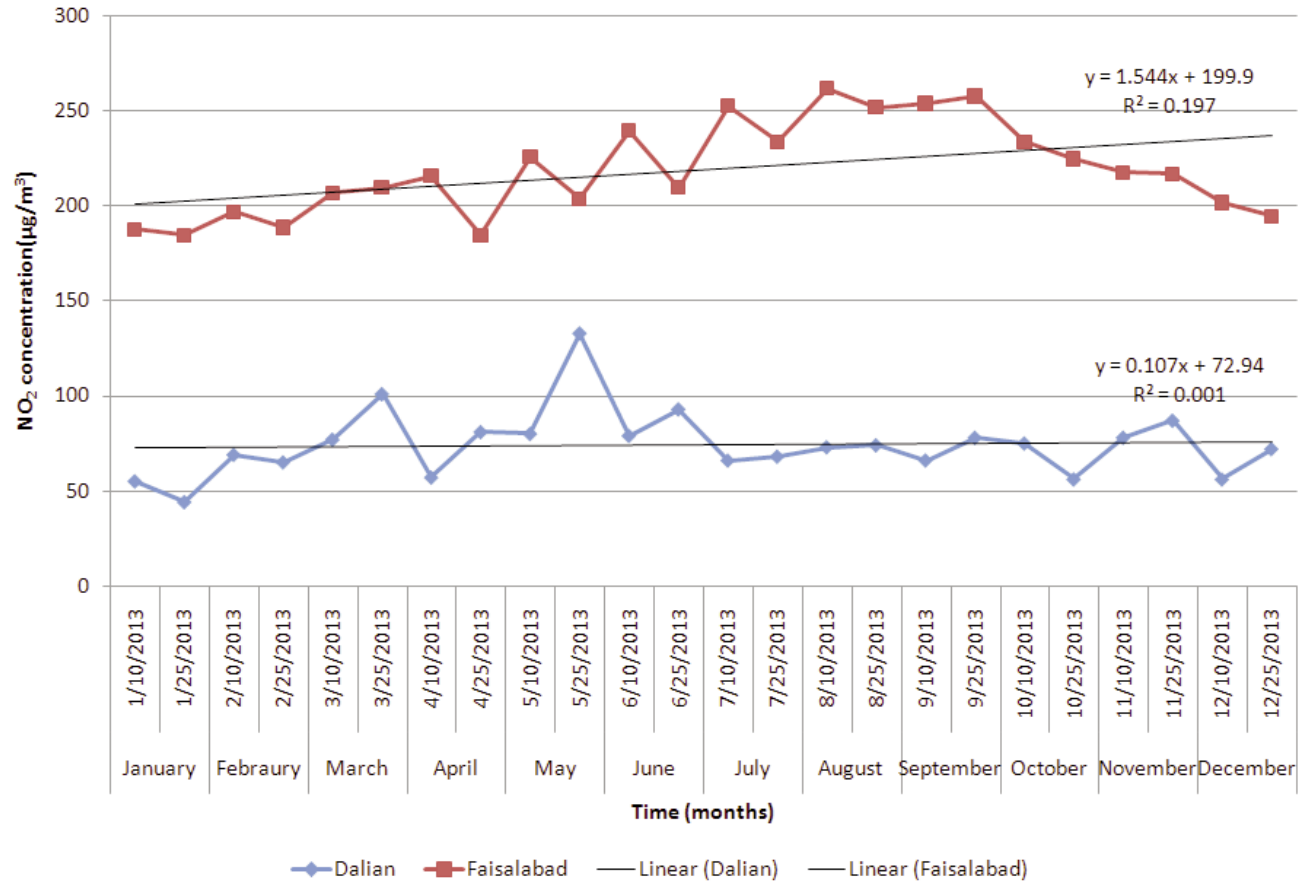

Fig. 4. Month-wise comparison of $\mathrm{NO}_{2}$ concentrations between Dalian and Faisalabad.

Kolkata-India $\left(37 \mu \mathrm{g} / \mathrm{m}^{3}\right)$, but lower than Lahore-Pak (76 $\left.\mu \mathrm{g} / \mathrm{m}^{3}\right)$, Karachi-Pak $\left(76 \mu \mathrm{g} / \mathrm{m}^{3}\right)$, and Beijing-China (122 $\left.\mu \mathrm{g} / \mathrm{m}^{3}\right)[21,22]$. The minimum value of $\mathrm{NO}_{2}$ concentration was $44 \mu \mathrm{g} / \mathrm{m}^{3}$ in January 2013, whereas the maximum (133 $\left.\mu \mathrm{g} / \mathrm{m}^{3}\right)$ was in May 2013. The average $\mathrm{NO}_{2}$ concentration during the cold period (10 October to 25 March) was $69 \mu \mathrm{g} / \mathrm{m}^{3}$, and within the permissible limits of NEQS, USEPA, and CNAAQS, but higher than the WHO limit. The corresponding concentration for the warm period (10 April to 25 September) was $79 \mu \mathrm{g} / \mathrm{m}^{3}$, which was also higher than the WHO $\left(40 \mu \mathrm{g} / \mathrm{m}^{3}\right)$ limit. But within the permissi- ble limits of USEPA, NEQS, and CNAAQS limits of 100, $80,80 \mu \mathrm{g} / \mathrm{m}^{3}$, respectively (Table 2 ).

Overall, $80 \%$ of the values of $\mathrm{NO}_{2}$ concentrations in Dalian city (date wise) were within the permissible limits of CNAAQS and NEQS, whereas $91 \%$ were within the USEPA standard and beyond WHO limits (Table 2). In comparison to standards, $100 \%$ of $\mathrm{NO}_{2}$ values were beyond the permissible limits. Furthermore, the average $\mathrm{NO}_{2}$ concentration in Faisalabad city in dry season was higher than the wet season, and the same was observed for Dalian city. The monthly comparison of $\mathrm{NO}_{2}$ is shown in

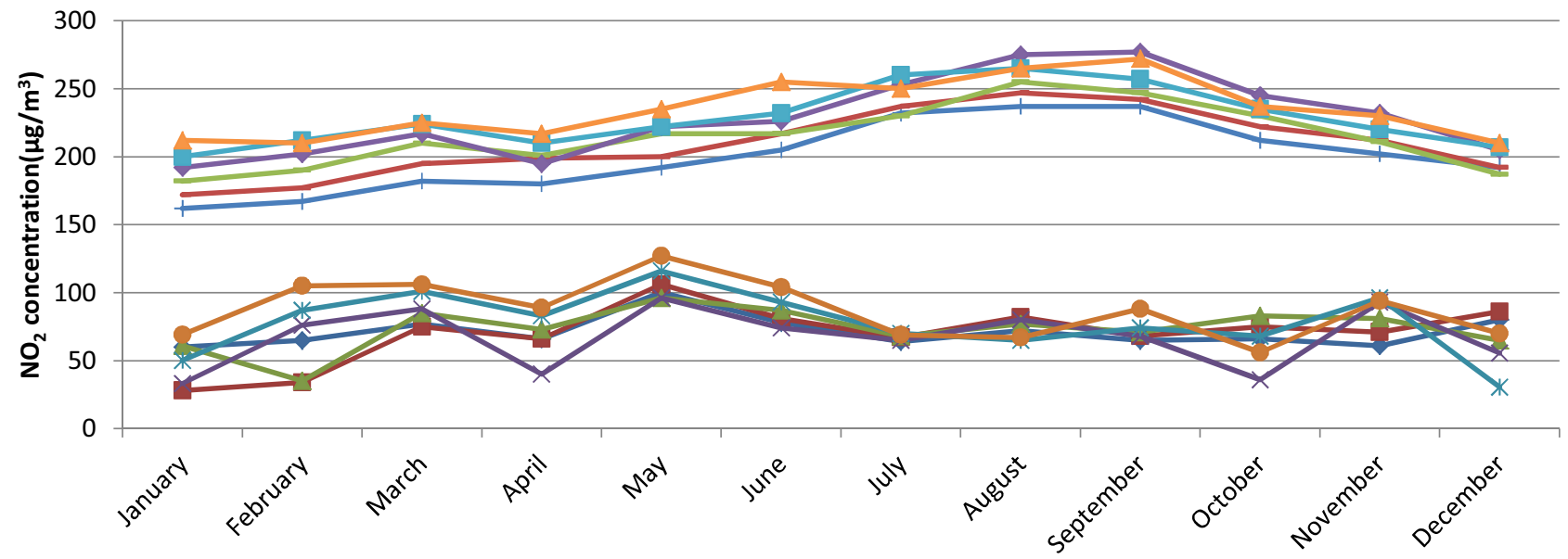

Months

$\begin{array}{ll}\sim \text { Ganjingzi } & - \text { Zhoushuizi } \\ \leftarrow \text { Qingniwaqiao } & \approx \text { Fujiazhuang } \\ + \text { Clock Tower Sq. } & - \text { Station Chowk Sq. }\end{array}$

Fig. 5. Station-wise comparison of $\mathrm{NO}_{2}$ concentrations in Dalian and Faisalabad. 
Fig. 4. We observed that in Dalian in May there was a sudden increase in $\mathrm{NO}_{2}$ concentration, although in the remaining period the trend was almost the same. The value of linear co-relation coefficient $\mathrm{R}^{2}$ for Dalian is 0.001 and it was 0.197 for Faisalabad.

The $\mathrm{NO}_{2}$ concentrations recorded at different stations throughout the year in Dalian and Faisalabad are shown in Fig. 5. These six monitoring sites in both cities selected randomly are residential, commercial, industrial, and vehicular areas. The minimum and maximum annual average values of $\mathrm{NO}_{2}$ concentration in Faisalabad were recorded at Clock Tower Square and Millat Square at $200 \mu \mathrm{g} / \mathrm{m}^{3}$ and 234 $\mu \mathrm{g} / \mathrm{m}^{3}$, respectively, and were beyond the permissible limits set by NEQS, USEPA, WHO, and CNAAQS. The minimum and maximum annual average values of $\mathrm{NO}_{2}$ in Dalian were recorded at Qingniwa and at Qixianling as 67 $\mu \mathrm{g} / \mathrm{m}^{3}$ and $87 \mu \mathrm{g} / \mathrm{m}^{3}$, respectively, and were within the limits of NEQS, USEPA, and CNAAQS, but higher than the WHO standards. Station-wise, $\mathrm{NO}_{2}$ concentration results show that $\mathrm{NO}_{2}$ was significantly higher in Faisalabad versus Dalian at all stations.

\section{Comparison of $\mathrm{SO}_{2}$ at Dalian and Faisalabad Cities}

The concentrations of $\mathrm{SO}_{2}$ were recorded from January to December 2013 and the trend thus observed at Faisalabad and Dalian stations is shown in Fig. 6. $\mathrm{SO}_{2}$ concentrations in Faisalabad varied from 66 to $190 \mu \mathrm{g} / \mathrm{m}^{3}$ with average values of $134 \mu \mathrm{g} / \mathrm{m}^{3}$. These concentrations were relatively higher than the other cities in the region, such as Lahore-Pak (115 $\left.\mu \mathrm{g} / \mathrm{m}^{3}\right)$, Karachi-Pak $\left(30 \mu \mathrm{g} / \mathrm{m}^{3}\right)$, Islamabad-Pak $\left(73.4 \mu \mathrm{g} / \mathrm{m}^{3}\right)$, Beijing-China $\left(120 \mu \mathrm{g} / \mathrm{m}^{3}\right)$,
Shanghai-China $\left(53 \mu \mathrm{g} / \mathrm{m}^{3}\right)$, Tokyo-Japan $\left(19 \mu \mathrm{g} / \mathrm{m}^{3}\right)$, Mumbai-India $\left(18 \mu \mathrm{g} / \mathrm{m}^{3}\right)$, and Kolkata-India $\left(19 \mu \mathrm{g} / \mathrm{m}^{3}\right)$ [22-24]. The minimum value of $\mathrm{SO}_{2}$ concentration was recorded $66 \mu \mathrm{g} / \mathrm{m}^{3}$ in February 2013, whereas the maximum $\left(190 \mu \mathrm{g} / \mathrm{m}^{3}\right)$ was detected in July 2013 . The average $\mathrm{SO}_{2}$ concentration during the cold period (10 November to $25 \mathrm{March}$ ) was $108 \mu \mathrm{g} / \mathrm{m}^{3}$ and was within the permissible limits of NEQS, USEPA, and CNAAQS, but higher than the limit set by WHO. The average concentration in warm period (10 April to 25 October) was recorded to be 152 $\mu \mathrm{g} / \mathrm{m}^{3}$ and was beyond the permissible limits of NEQS, CNAAQS, and WHO, while within the USEPA range. Overall, $25 \%$ of recorded values were found within the permissible limit of NEQS, 100\% within the limits of USEPA, and $66 \%$ within the standards of CNAAQS, but $100 \%$ of values were beyond the limit set by WHO (Table 2). The $\mathrm{SO}_{2}$ concentrations in Dalian varied from 56 to $128 \mu \mathrm{g} / \mathrm{m}^{3}$, with an average of $103 \mu \mathrm{g} / \mathrm{m}^{3}$.

These concentrations are relatively higher than other cities in the regions, like Karachi-Pak $\left(30 \mu \mathrm{g} / \mathrm{m}^{3}\right)$, Islamabad-Pak $\left(73.4 \mu \mathrm{g} / \mathrm{m}^{3}\right)$, Shanghai-China $\left(53 \mu \mathrm{g} / \mathrm{m}^{3}\right)$, Tokyo-Japan $\left(19 \mu \mathrm{g} / \mathrm{m}^{3}\right)$, Mumbai-India $\left(18 \mu \mathrm{g} / \mathrm{m}^{3}\right)$, and Kolkata-India $\left(19 \mu \mathrm{g} / \mathrm{m}^{3}\right)$, but lower than Beijing-China $\left(120 \mu \mathrm{g} / \mathrm{m}^{3}\right)$ and Lahore-Pak $\left(115 \mu \mathrm{g} / \mathrm{m}^{3}\right)$ [22-24]. The minimum value of $\mathrm{SO}_{2}$ concentration was $56 \mu \mathrm{g} / \mathrm{m}^{3}$ in January 2013 , whereas the maximum $\left(128 \mu \mathrm{g} / \mathrm{m}^{3}\right)$ was recorded in June 2013. The average $\mathrm{SO}_{2}$ concentration in Dalian was low year-round, but there was a sudden increase found in April to September 2013. The average $\mathrm{NO}_{2}$ concentration during the cold period (10 October to $25 \mathrm{March}$ ) was found to be $95 \mu \mathrm{g} / \mathrm{m}^{3}$, whereas it was $111 \mu \mathrm{g} / \mathrm{m}^{3}$ in the warm period (10 April to 25 September) and was within the permissible limits of NEQS, USEPA, and CNAAQS, but higher versus the WHO standard.

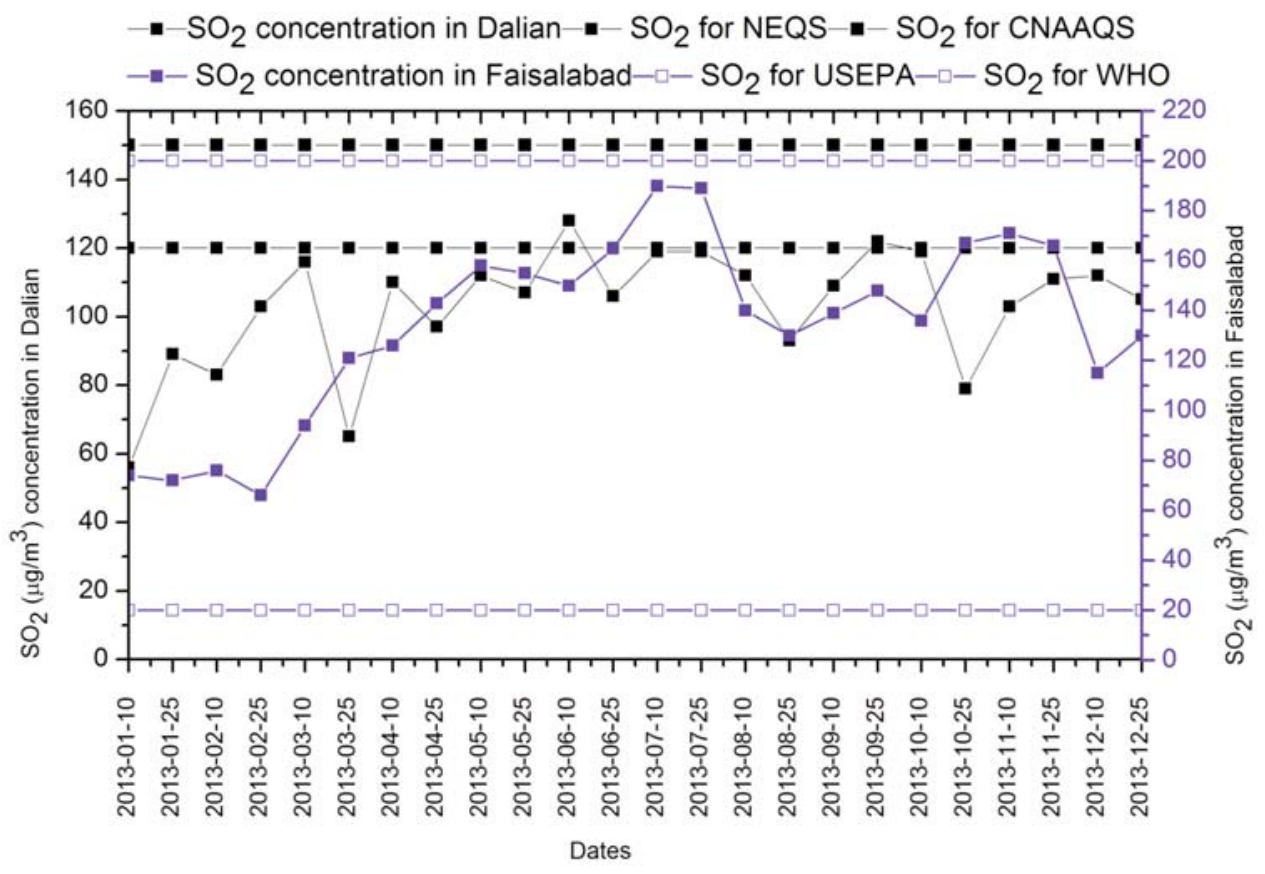

Fig. 6. Date-wise comparison of $\mathrm{SO}_{2}$ concentrations between Dalian and Faisalabad. 


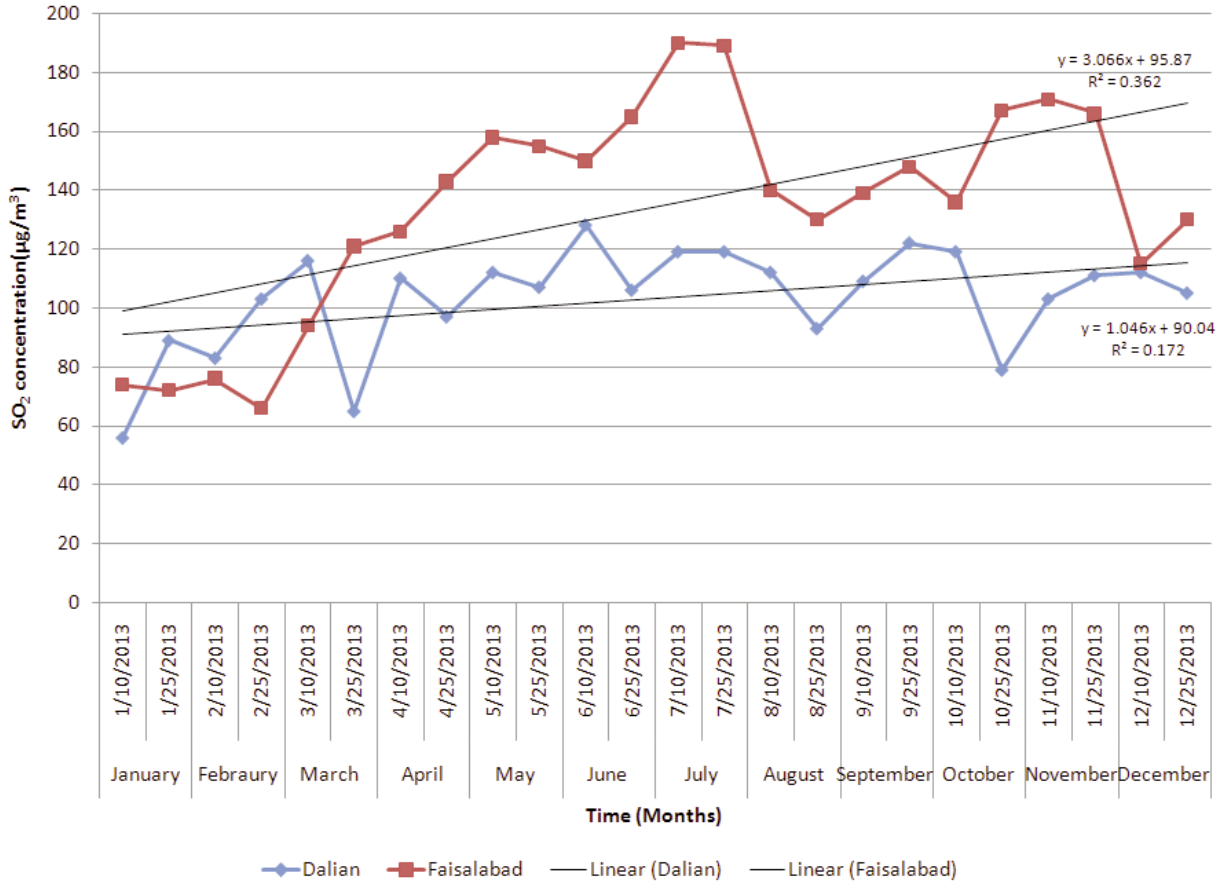

Fig. 7. Date-wise comparison of $\mathrm{SO}_{2}$ concentrations between Dalian and Faisalabad.

Overall, $87 \%$ of values fall within the limit of NEQS, $100 \%$ of values within the USEPA limit, $100 \%$ of values within the CNAAQS standard, and $100 \%$ values were beyond the WHO limits (Table 2). Fig. 7 shows the $\mathrm{SO}_{2}$ concentration month-wise in Faisalabad and Dalian. The $\mathrm{SO}_{2}$ concentration in Faisalabad in June and July showed a sudden increase in concentration. The value of $\mathrm{R}^{2}$ for Dalian was 0.172 and for Faisalabad it was 0.362 , which indicates a significant variation in $\mathrm{SO}_{2}$ concentration in Faisalabad versus Dalian. Fig. 8 shows the station-wise comparison of $\mathrm{SO}_{2}$ concentrations in Dalian and
Faisalabad. The minimum and maximum annual average values of $\mathrm{SO}_{2}$ concentrations in Faisalabad was recorded at Chenab Chowk Square $\left(130 \mu \mathrm{g} / \mathrm{m}^{3}\right)$ and Millat Square (138 $\mu \mathrm{g} / \mathrm{m}^{3}$ ), respectively, whereas the minimum and maximum annual average values of $\mathrm{SO}_{2}$ concentration in Dalian were recorded at Zhoushuizi $\left(88 \mu \mathrm{g} / \mathrm{m}^{3}\right)$ and Xinghai (109 $\left.\mu \mathrm{g} / \mathrm{m}^{3}\right)$, which are in the limits set by NEQS, USEPA, and CNAAQS, but higher than the WHO standard. Station-wise $\mathrm{SO}_{2}$ concentration results shows that the level of $\mathrm{SO}_{2}$ in Faisalabad was significantly higher than Dalian-China at all selected stations.

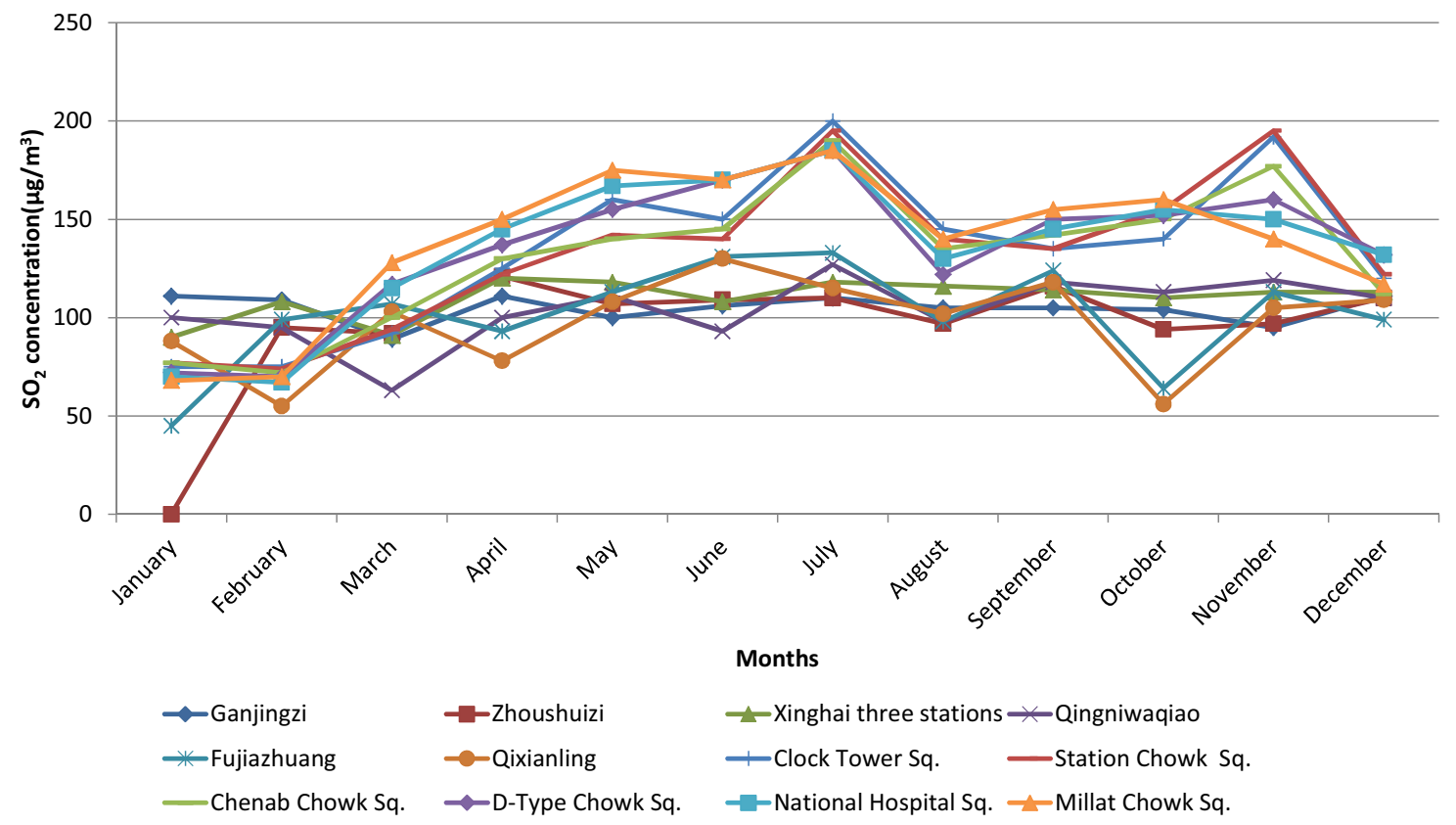

Fig. 8. Station-wise comparison of $\mathrm{SO}_{2}$ concentrations between Dalian and Faisalabad. 


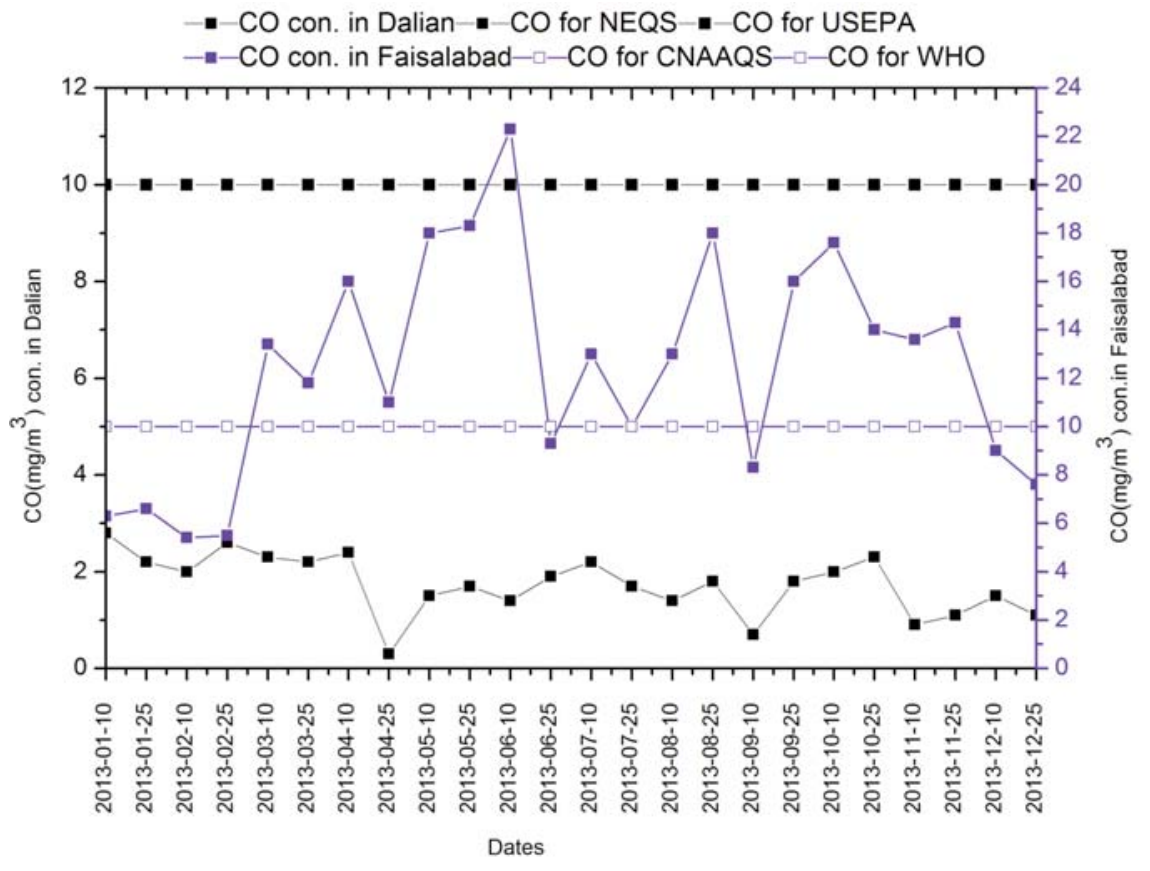

Fig. 9. Date-wise comparison of CO concentrations between Dalian and Faisalabad.

\section{Comparison of $\mathrm{CO}$ in Dalian and Faisalabad}

How CO concentrations in Faisalabad and Dalian differ year-round is shown in Fig. 9. In Faisalabad CO concentrations varied from 5.4 to $22.3 \mathrm{mg} / \mathrm{m}^{3}$, with an average of 12.4 $\mathrm{mg} / \mathrm{m}^{3}$. These concentrations are relatively higher than for other cities in the regions, like Lahore-Pak $\left(4.6 \mathrm{mg} / \mathrm{m}^{3}\right)$, Karachi-Pak $\left(5.8 \mathrm{mg} / \mathrm{m}^{3}\right)$, Islamabad-Pak $\left(3.5 \mathrm{mg} / \mathrm{m}^{3}\right)$, Beijing-China $\left(2 \mathrm{mg} / \mathrm{m}^{3}\right)$, Shanghai-China $\left(6.6 \mathrm{mg} / \mathrm{m}^{3}\right)$,
Guangzhou-China $\left(1.6 \mathrm{mg} / \mathrm{m}^{3}\right)$, Dhaka-Bangladesh $(0.166$ $\mathrm{mg} / \mathrm{m}^{3}$ ), and Kolkata-India $\left(3.61 \mathrm{mg} / \mathrm{m}^{3}\right)$ [9, 25-28]. The minimum value of $\mathrm{CO}$ was $5.4 \mathrm{mg} / \mathrm{m}^{3}$ in February 2013, whereas the maximum $\left(22.3 \mathrm{mg} / \mathrm{m}^{3}\right)$ was recorded in July 2013. The average CO concentration during the cold period (10 November to $25 \mathrm{March}$ ) was $9.35 \mathrm{mg} / \mathrm{m}^{3}$, and within the NEQS, USEPA, WHO, and CNAAQS limits, whereas in the warm period (10 April to 25 October) it was $14.6 \mathrm{mg} / \mathrm{m}^{3}$ and beyond the permissible limits of NEQS,

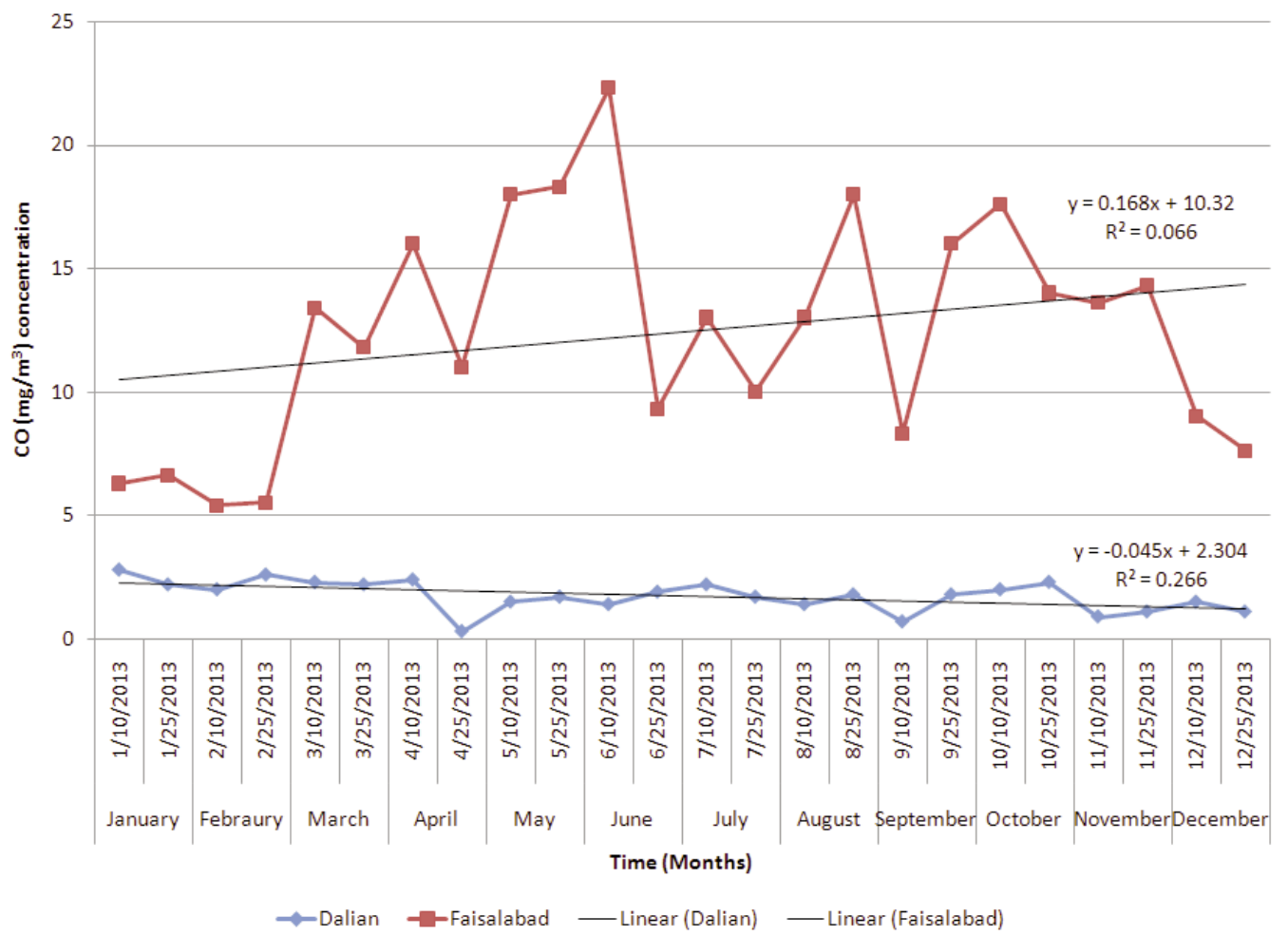

Fig. 10. Month-wise comparison of CO concentrations in Dalian and Faisalabad. 


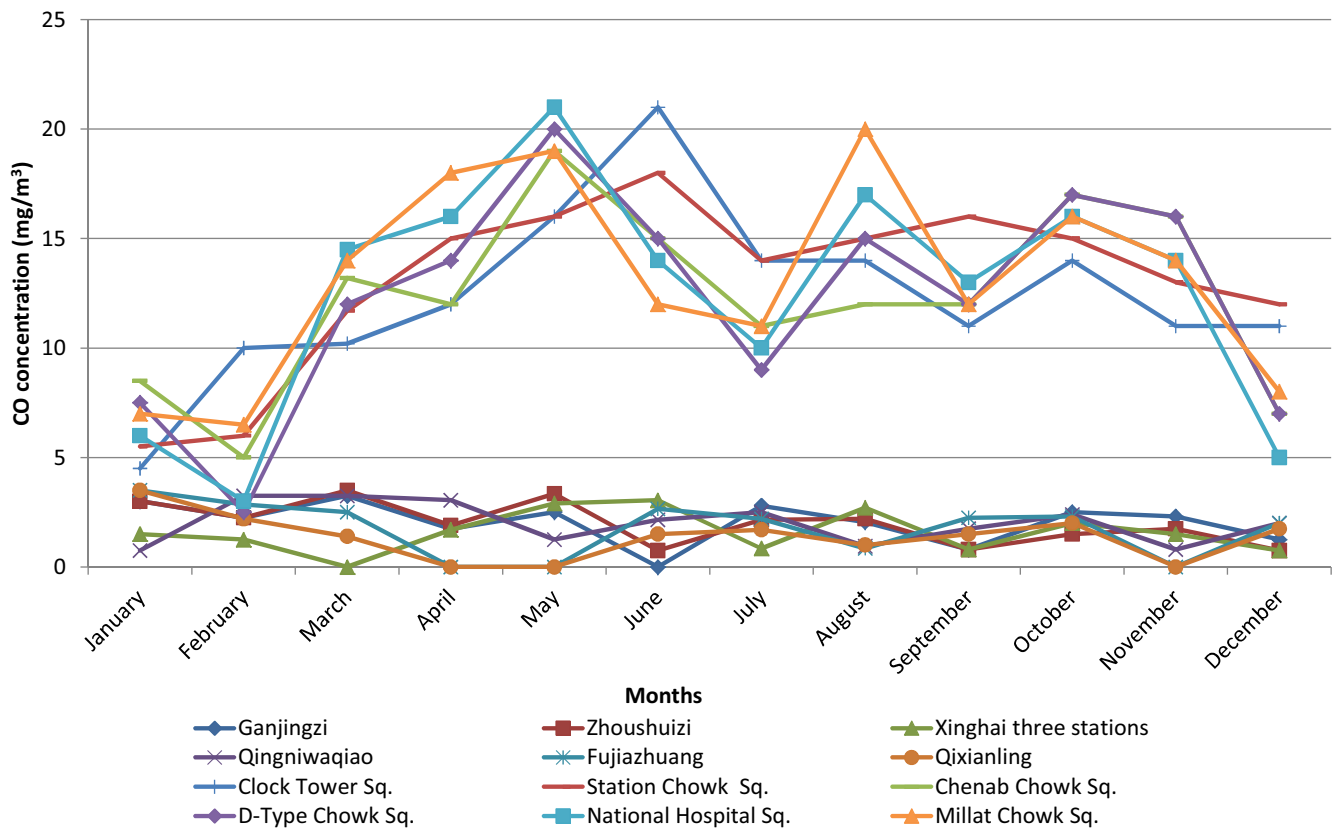

Fig. 11. Month-wise comparison of CO concentrations in Dalian and Faisalabad.

CNAAQS, WHO, and USEPA standards. Overall it was observed that $37 \%$ values were within the permissible limit of NEQS, USEPA, CNAAQS, and WHO (Table 2). Similarly, at Dalian CO concentration varied from 0.3 to 2.8 $\mathrm{mg} / \mathrm{m}^{3}$ with an average of $1.83 \mathrm{mg} / \mathrm{m}^{3}$. These concentrations are relatively lower than Lahore-Pak $\left(4.6 \mathrm{mg} / \mathrm{m}^{3}\right)$, KarachiPak $\left(5.8 \mathrm{mg} / \mathrm{m}^{3}\right)$, Islamabad-Pak $\left(3.5 \mathrm{mg} / \mathrm{m}^{3}\right)$, Beijing-China $\left(2 \mathrm{mg} / \mathrm{m}^{3}\right)$, Shanghai-China $\left(6.6 \mathrm{mg} / \mathrm{m}^{3}\right)$, and Kolkata-India (3.61 $\left.\mathrm{mg} / \mathrm{m}^{3}\right)$, but higher than Guangzhou-China (1.6 $\left.\mathrm{mg} / \mathrm{m}^{3}\right)$ and Dhaka-Bangladesh $\left(0.166 \mathrm{mg} / \mathrm{m}^{3}\right)$ [9, 25-28].

The minimum CO concentration was recorded at 0.3 $\mathrm{mg} / \mathrm{m}^{3}$ in April 2013, whereas the maximum of $2.8 \mathrm{mg} / \mathrm{m}^{3}$ in January, 2013. The average CO concentration during the cold period (10 October to $25 \mathrm{March}$ ) was $1.91 \mathrm{mg} / \mathrm{m}^{3}$, within the permissible limits set by NEQS, USEPA,WHO, and CNAAQS, and during the warm period (10 April to 25 September) it was $1.56 \mathrm{mg} / \mathrm{m}^{3}$ - also within permissible limits. Overall, $100 \%$ of annual CO values were lower than the limits set by NEQS, USEPA, CNAAQS, and WHO (Table 2). Fig. 10 shows analysis of $\mathrm{CO}$ concentrations by date and month in Faisalabad and Dalian. CO concentrations in Faisalabad from February to June 2013 increased and then decreased. The variation in $\mathrm{CO}$ concentration was not so pronounced in Dalian versus Faisalabad, and the $\mathrm{R}^{2}$ for Dalian is 0.266 and 0.066 for Faisalabad. Fig. 11 shows the station comparison of $\mathrm{CO}$ concentrations in Dalian and Faisalabad. The minimum and maximum annual average values in Faisalabad were recorded at D-Type Chowk Square and Station Chowk Square of $12 \mathrm{mg} / \mathrm{m}^{3}$ and $13.1 \mathrm{mg} / \mathrm{m}^{3}$, respectively, and these both minimum and maximum values were beyond the limits set by NEQS, WHO, USEPA, and CNAAQS. The minimum and maximum annual average values of CO concentrations in Dalian were recorded at Qixianling $\left(1.37 \mathrm{mg} / \mathrm{m}^{3}\right)$ and Ganjingzi $\left(2.03 \mathrm{mg} / \mathrm{m}^{3}\right)$.

\section{Conclusions}

$\mathrm{NO}_{2}, \mathrm{SO}_{2}$, and $\mathrm{CO}$ concentrations were measured in the ambient air at various stations in Dalian, China and Faisalabad, Pakistan for one year from January to December 2013. The $\mathrm{NO}_{2}$ concentrations in Faisalabad varied from $185-262 \mu \mathrm{g} / \mathrm{m}^{3}$, whereas it was in the range of 44 $133 \mu \mathrm{g} / \mathrm{m}^{3}$ in Dalian. $\mathrm{SO}_{2}$ concentrations were found in the range of $66-190 \mu \mathrm{g} / \mathrm{m}^{3}$ and $56-128 \mu \mathrm{g} / \mathrm{m}^{3}$, while $\mathrm{CO}$ varied from $5.4-22.3 \mathrm{mg} / \mathrm{m}^{3}$ and $0.3-2.8 \mathrm{mg} / \mathrm{m}^{3}$, respectively, in Faisalabad and Dalian. The annual average $\mathrm{NO}_{2}, \mathrm{SO}_{2}$, and $\mathrm{CO}$ concentrations were below the permissible limits in Dalian, although the measured values were considerably higher in Faisalabad. The $\mathrm{NO}_{2}, \mathrm{SO}_{2}$, and $\mathrm{CO}$ concentrations were found to be significantly different in both cities. Furthermore, different stations within cities also showed a significant variation in ambient air quality. On an average basis it was observed that the $\mathrm{NO}_{2}, \mathrm{SO}_{2}$, and $\mathrm{CO}$ remained within the permissible limits set by NEQS, USEPA, and CNAAQS in Dalian city, whereas above the WHO limits and in Faisalabad, it was higher than NEQS, USEPA, CNAAQS, and WHO. Therefore, the air quality should be controlled by taking serious measures to avoid negative health impacts, especially in Faisalabad in comparison to Dalian.

\section{Acknowledgements}

The authors are very thankful to the Environment Protection Department of Faisalabad, Pakistan, and the Environmental Protection Bureau of Dalian in the People's Republic of China for providing support and assistance in this research. 


\section{References}

1. LIM L.L., HUGHES S.J., HELLAWELL E.E. Integrated Decision Support System for Urban Air Quality Assessment. Environ. Modell. Softw. 20, 947, 2005.

2. BASARIC V., DORIC V., BOGDAVONIC V., MITROVIC J., JOVIC J. Effects of Traffic on $\mathrm{NO}_{2}$ and $\mathrm{P}_{10}$ Emissions in Novi Sad. Pol. J. Environ. Stud. 23, (5), 1837, 2014.

3. TRAN C.L., BUCHANAN D., CULLEN R.T., SEARL A., JONES A.D., DONALDSON K. Inhalation of Poorly Soluble Particles. II. influence of Particle Surface Area on Inflammation and Clearance. Inhalation Toxicol. 12, 1113, 2000.

4. DONALDSON K., TRAN C.L., JIMENEZ L.A., DUFFIN R., NEWBY D., MILLS N., MACNEE W., STONE V. Combustion-derived Nanoparticles: A Review of Their Toxicology Following Inhalation Exposure. Part. Fibre Toxicol. 2, 10, 2005.

5. PEDEN D.B. The Epidemiology and Genetics of Asthma Risk Associated with Air Pollution. J. Allergy Clin. Immunol. 115, 213, 2005.

6. LI N., XIA T., NEL A.E. The Role of Oxidative Stress in Ambient Particulate Matter-Induced Lung Diseases and its Implications in the Toxicity of Engineered Nanoparticles. Free Radical Biol. Med. 44, 1689, 2008.

7. RIEDL M.A. The Effect of Air Pollution on Asthma and Allergy. Curr. Allergy Asthma Rep. 8, 139, 2008.

8. COLBECK I., NASIR Z.A., ALI Z. The state of ambient air quality in Pakistan - a review. Environ Sci. Pollut. Res. 17, 49, 2010.

9. CHAN C.K., YAO X. Air Pollution in Mega Cities in China. Atmos. Environ. 42, 1, 2008.

10. KAN H., CHEN R., TONG S. Ambient Air Pollution, Climate Change, and Population Health in China. Environ. Int. 42, 10, 2012.

11. SHAO M., TANG X., ZHANG Y., LI W. City Clusters in China: Air and Surface Water Pollution. Front. Ecol. Environ. 4, 353, 2006.

12. TIAN H.Z., HAO J.M., HU M.Y., NIE Y.F. Recent Trends of Energy Consumption and Air Pollution in China. J. Energy Eng. 133, 4, 2007.

13. YANG D.X., WANG Z.Q., ZHANG R.J. Estimating Air Quality Impacts of Elevated Point Source Emissions in Chongqing, China. Aerosol Air Qual. Res. 8, 279, 2008.

14. HAN S.Q., BIAN H., FENG Y.C., LIU A.X., LI X.J., ZENG F., ZHANG X.L. Analysis of the Relationship between $\mathrm{O}_{3}$, $\mathrm{NO}$ and $\mathrm{NO}_{2}$ in Tianjin, China. Aerosol Air Qual. Res. 11, 128, 2011.
15. YANG S.J., HE H.P., LU S.L., CHEN D., ZHU J.X. Quantification of Crop Residue Burning in the Field and Its Influence on Ambient Air Quality in Suqian, China. Atmos. Environ. 42, 1961, 2008.

16. WANG H., FU L., ZHOU Y., DU X., GE W. Trends in Vehicular Emissions in China's Mega Cities from 1995 to 2005. Environ. Pollut. 158, 394, 2010.

17. ZHAO Y., WANG S.X., DUAN L., LEI Y., CAO P.F., HAO J.M. Primary Air Pollutant Emissions of Coalfired Power Plants in China: Current Status and Future Prediction. Atmos. Environ. 42, 8442, 2008.

18. Pakistan Bureau of Statistics 2013. Pakistan Statistical Year Book 2012-13, 2013.

http://www.pbs.gov.pk/content/pakistan-statistical-yearbook-2012

19. Online available with updates http://www.faisalabad.gov.pk

20. Online available with updates http://www.epb.dl.gov.cn

21. Pak-EPA/JICA. Measurement of $\mathrm{NO}_{2}$ Concentration in Ambient Air in Major Cities of Pakistan Using Diffusion Samplers, 2006.

Available at: http://www.environment.gov.pk/news.htm Accessed on 3 July 2008.

22. GURJARA B.R., BUTLER T.M., LAWRENCE M.G., LELIEVELD J. Evaluation of emissions and air quality in megacities. Atmos. Environ. 42, 1593, 2008.

23. Pak-EPA/JICA. 3 Cities Investigation of Air and Water Quality (Lahore, Rawalpindi \& Islamabad), JICA-Pak-EPA, June, 2001.

Available at: http://www.environment.gov.pk/pub-pdf/3cityinv.pdf.accessed on 3 July 3, 2008.

24. Pak-EPA/JICA. 2 Cities Investigation of Air and Water Quality (Gujranwala, Faisalabad), JICA-Pak-EPA, November 2003, 2001.

Available at: http://www.environment.gov.pk/pub-pdf/ accessed on 3 July, 2008.

25. GHOSE M.K., PAUL R., BANERJEE S.K. Assessment of the impacts of vehicular emissions on urban air quality and its management in Indian context: the case of Kolkata (Calcutta). Environ. Sci. \& Policy. 7, (4), 345, 2004.

26. YE B., JI X., YANG H., YAO X., CHAN C.K., CADLE S.H., CHAN T., MULAWA P.A. Concentration and chemical composition of $\mathrm{PM}_{2.5}$ in Shanghai for 1-year period. Atmosp. Environ. 37, 499, 2003.

27. GHAURI B., LODHI A., MANSHA M. Development of baseline (air quality) data in Pakistan. Environ. Monit. Assess. 127, 237, 2007.

28. SALAM A., HOSSAIN T., SIDDIQUE M.N.A., SHAFIQULA.S. Characteristics of atmospheric trace gases, particulate matter, and heavy metal pollution in Dhaka, Bangladesh. Air Qual. Atmos Health. 1, (2), 101, 2008. 